\title{
Change is the only constant
}

\author{
Michael J. Reardon, MD
}

From the Department of Cardiothoracic Surgery, Houston Methodist Hospital, Houston, Tex.

Disclosures: Author has nothing to disclose with regard to commercial support.

Received for publication March 20, 2017; accepted for publication March 21, 2017; available ahead of print April 27, 2017.

Address for reprints: Michael J. Reardon, MD, Houston Methodist Hospital, Cardiothoracic Surgery, 6550 Fannin

St, Suite 1401, Houston, TX 77030 (E-mail: mreardon@houstonmethodist.org).

J Thorac Cardiovasc Surg 2017;154:996-7

$0022-5223 / \$ 36.00$

Copyright (c 2017 by The American Association for Thoracic Surgery

http://dx.doi.org/10.1016/j.jtcvs.2017.03.100

\section{Change is the only constant.}

\section{-Aphorism ascribed to \\ Heraclitus of Ephesus (535-475 BCE)}

From the Greek philosopher Heraclitus of Ephesus, who stated that change is central to the universe, to Bob Dylan, who said, "The times they are a-changin'," we have been told that change is inevitable. An aphorism often-if dubiously—attributed to Darwin runs, "It is not the strongest of the species that survives, nor the most intelligent that survives. It is the one that is most adaptable to change." Change is inevitable in this life, and our ability to adapt to that change often defines our success in life. That does not, however, mean that we always accept this change. I remember as a young (very young) surgical resident hearing a senior cardiac surgeon who was a pioneer in the field complain that before cardioplegia only a few surgeons could do heart surgery, whereas after cardioplegia every surgeon could do heart surgery. It is true that cardioplegia helped move cardiac surgery out of the hands of only those who were exceptionally fast and technically gifted to a broader group of surgeons with continued good results. That may have been bad for the gifted few who had established the beachhead for cardiac surgery, but it was undoubtedly better for the field and our patients. In today's world, cardiac surgeons have led the way in pursuing less invasive surgical approaches in the operating room while watching a continued encroachment by catheter-based therapies.

Earlier cardiac surgeons watched as catheter-based approaches to coronary disease grew at a great rate, encroaching on the coronary artery bypass grafting operations that formed the bulk of many cardiac surgical practices. Now cardiac surgeons are watching the exponential growth of transcatheter aortic valve replacement (TAVR), with the promise of more structural heart problems to fall to catheter-based treatment. We now have in the literature 2 randomized trials comparing TAVR with surgery for high-risk patients, with one showing noninferiority to surgery ${ }^{1}$ and the other showing superiority. $^{2}$ We also have 2 intermediate-risk trials comparing TAVR with surgery, with both showing noninferiority. ${ }^{3,4}$

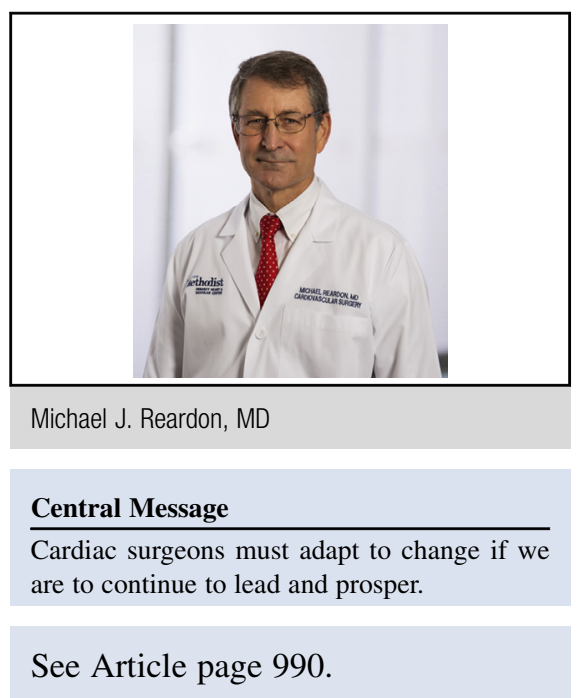

Two low-risk randomized trials, the Safety and Effectiveness of the SAPIEN 3 Transcatheter Heart Valve in Low Risk Patients With Aortic Stenosis (P3) trial (PARTNER III; NCT02675114) and Medtronic Transcatheter Aortic Valve Replacement in Low Risk Patients (NCT02701283), are also actively recruiting. If the low-risk trials demonstrate noninferiority, cardiac surgeons fear that any patient with symptomatic severe aortic stenosis who is a candidate for a bioprosthetic valve may instead undergo TAVR. There are unquestionably issues with TAVR that have not yet been fully solved, such as durability, paravalvular leakage, and pacemaker, but the rapid progression of the field indicates a high probability that they will be solved.

I was recently involved in a debate at one of our meetings on TAVR versus surgery for the patient at low risk, and I was assigned the side in favor of surgery. It is difficult to argue the high-risk and intermediate-risk data. In the high-risk trial that showed superior survival with TAVR to that with surgery, we looked at the cause and timing of death in both arms of the trial. ${ }^{5}$ Interestingly, the only period that actually showed superior survival for TAVR was the 1- to 4-month period. This was the period when patients in the high-risk surgical group were discharged from the hospital, often to extended-stay facilities, but did not have the physiologic reserve to recover from the surgery. This effect would decrease in the intermediate-risk group and decrease even further in the low-risk group, but this decrease is likely only to make surgery and TAVR equivalent. My argument for surgery was that if surgery is considered to encompass procedures done by cardiac surgeons, then cardiac surgeons 
who can do both TAVR and traditional surgery will win, and we will look more like our vascular colleagues who have mastered both. To do this, we need both revamp both our educational system and our concept of what it means to be a cardiac surgeon. The article in this issue of the Journal by Pelletier and colleagues, "From Sutures to Wires: The Evolving Necessities of Cardiac Surgery Training," provides a good blueprint for this transition. They have laid out a promising path, but it is up to cardiac surgeons, both young and old, to seize on this opportunity and not be left behind again.

Come gather 'round people

Wherever you roam

And admit that the waters

Around you have grown

And accept it that soon

You'll be drenched to the bone

If your time to you

Is worth savin'
Then you better start swimmin' or you'll sink like a stone For the times they are a-changin'

-Bob Dylan

“The Times They Are A-Changin"” (1963)

\section{References}

1. Smith CR, Leon MB, Mack MJ, Miller DC, Moses JW, Svensson LG, et al; PARTNER Trial Investigators. Transcatheter versus surgical aortic-valve replacement in high-risk patients. N Engl J Med. 2011;364:2187-98.

2. Reardon MJ, Adams DH, Kleiman NS, Yakubov SJ, Coselli JS, Deeb GM, et al 2-Year outcomes in patients undergoing surgical or self-expanding transcatheter aortic valve replacement. J Am Coll Cardiol. 2015;66:113-21.

3. Leon MB, Smith CR, Mack MJ, Makkar RR, Svensson LG, Kodali SK, et al; PARTNER 2 Investigators. Transcatheter or surgical aortic-valve replacement in intermediate-risk patients. $N$ Engl J Med. 2016;374:1609-20.

4. Reardon MJ, Van Mieghem NM, Popma JJ, Kleiman NS, Søndergaard L, Mumtaz M, et al; SURTAVI Investigators. Surgical or transcatheter aortic-valve replacement in intermediate-risk patients. N Engl J Med. 2017;376:1321-31.

5. Gaudiani V, Deeb GM, Popma JJ, Adams DH, Gleason TG, Conte JV, et al. Causes of death from the randomized CoreValve US Pivotal High-Risk Trial. J Thorac Cardiovasc Surg. 2017;153:1293-301.

6. Pelletier MP, Kaneko T, Peterson MD, Thourani VH. From sutures to wires: the evolving necessities of cardiac surgery training. J Thorac Cardiovasc Surg. 2017:154:990-3. 